\title{
Európa Kulturális Fóvárosa projekt: A veszprémi, győri és debreceni pályázatok összehasonlító elemzése
}

\section{European Capitals of Culture Project: A Comparative Analysis of the Applications Submitted by Veszprém, Gyór and Debrecen}

\section{Összefoglalás}

Az Európa Kulturális Fôvárosa cím 1985 óta nagy presztízsú európai kulturális programsorozat. Napjainkig mintegy 60 város viselte büszkén a címet. A projekt egy egész éven át tartó kulturális rendezvénysorozatot foglal magában, ezenfelül számos más funkciója, hatása is van, többek között városfejlődési katalizátor szerepét is betölti. 2023-ban magyar város lesz Európa Kulturális Fôvárosa, mely címért Gyôr, Debrecen és Veszprém álltak versenyben, végül Veszprém kerekedett felül. Azonban mindhárom pályázó fejlesztési terveket épített bele a koncepciójába, melyek több évtizedre is meghatározhatják e városok fejlôdési pályáját, nemcsak kulturális, hanem társadalmi és gazdasági értelemben is. A tanulmányban e tervek összehasonlítására kerül sor annak érdekében, hogy megismerjük a kulturális ambíciókkal rendelkezô magyar városok városfejlődési vízióit, irányait.

Journal of Economic Literature (JEL) kódok: R11, R58

Kulcsszavak: Európa Kulturális Fôvárosa, kultúra, városfejlődés, magyar városok

Morvay Szabolcs, doktorandusz, Széchenyi István Egyetem (morvay.szabolcs@sze.hu). 
Morvay Szabolcs: Európa Kulturális Fốvárosa projekt: A veszprémi, gyốri és debreceni...

\section{Summary}

The European Capitals of Culture has been a prestigious European cultural programme since 1985. Up to now, about 60 cities have been the proud owners of the title. The project includes a series of cultural events throughout the year, but it also has many other functions and effects, including the acceleration of city development. In 2023 a Hungarian city will be the European Capital of Culture, and three cities: Gyôr, Debrecen and Veszprém have competed for the title. Finally, Veszprém was granted the ECoC title. Nevertheless, all the three applicants have developed their plans into concepts to determine the development trajectories of these cities for decades in terms of cultural relations and in social and economic aspects. In the study, these plans are compared in order to discover the Hungarian city's vision and directions of its evolution.

Journal of Economic Literature (JEL) codes: R11, R58

Keywords: European Capital of Culture, culture, city development, Hungarian cities

\section{BEVEZETÉS}

2017 decemberében hét magyar város adta le a pályázatát az Emberi Erőforrások Minisztériumának: Győr, Szombathely, Veszprém, Székesfehérvár, Gödöllő, Eger és Debrecen. A pályázat nemzetközi, független szakértôi testülete a második fordulóra három magyar városnak adott esélyt a további küzdelemre, Gyôr, Debrecen és Veszprém maradt talpon. Az Európai Bizottság szakértôii különbözô kritériumok alapján bírálták el a pályázatokat. A végleges döntést, hogy Veszprém lesz Európa Kulturális Fóvárosa 2023-ban, 2018 végén hozta meg a tanácsadó testület, mely határozatot a magyar kormány jóváhagyta és véglegesítette.

Mindazonáltal izgalmas kérdés, hogy a kulturális ambíciókkal rendelkezô magyar városok milyen fejlódési utat túznek ki maguk elé a kultúra területén, hogyan kívánják mozgósítani lakosaikat a kultúra irányába, és milyen együttmúködéseket irányoznak elô saját térségükben és a tágabb dimenziókban. A három magyar város pályázatai alapot és forrást adnak a kérdések megválaszolásához, egyben a tanulmány célja ezen kérdésekre való válaszkeresésen túl a pályázatok összehasonlítása, „egymás mellé helyezése", hiszen a különbözôségek felderítése mindig a tudás legfóbb forrása volt, egy közös cél, a kultúra városépítô erejének kiaknázása érdekében érdemes minden elképzelést, víziót, technikát számba venni. Az analízis által gazdag és átfogó képet kaphatunk három magyar város kultúrával kapcsolatos gondolkodásáról. A tanulmány elméleti fejezete az Európa Kulturális Fôvárosa kezdeményezés bemutatásával indul, majd a projekt céljainak megismerésén keresztül eljutunk az egyetlen megvalósult magyar EKF, Pécs 2010-es tapasztalataihoz, mely tanulságok fontosak a jövôbeli EKF számára. Ezt követôen bemutatásra kerülnek a három város fejlôdési folyamatai, gazdasági-társadalmi és kulturális helyzetük. A gyakorlati fejezetben a pá- 
lyázatokkal foglalkozunk, az ambíciókkal, a kulturális profillal, illetve a programok koncepcióival. Kiderül számunkra, hogy a három város milyen hosszú távú hatásokat várt volna az EKF-programjától, milyen múvészeti és kulturális tartalommal töltötte volna fel a programsorozatát, végül milyen szervezeti keretek között képzelték el a megvalósítást.

\section{EuRóPA KuLTURÁlis FôvÁrosa KEZdEMÉnYEZÉS}

Az Európa Kulturális Fơvárosa kezdeményezés alapgondolata 1983-ban született meg, amikor Melina Mercouri görög kultuszminiszter, egykori színésznô a kulturális miniszterek athéni találkozóján azzal az ötlettel állt elő, hogy ne csak a gazdasági szektorok kapjanak figyelmet az uniós fejlesztési programokban, hanem a múvészetek, a kultúra is egyenrangú területként álljon az Európai Közösség támogatáspolitikájában. Hiszen az európai egység felé vezetô út egymás kultúrájának megismerésén keresztül vezet, és a program rávilágít, milyen gazdag, sokszínú kultúrával bír Európa. A program keretén belül minden évben egy, maximum három várost Európa Kulturális Fôvárosává jelölnek ki, mely városok ezáltal megismertethetik saját kulturális értékeiket. Az Európai Unió Tanácsa 1985-ben indította el a projektet, elsôként Athénban, majd az elmúlt több mint három évtizedben mintegy 60 városban (EC, 2009).

A projektnek otthont adó városok az évek során víziók és célok számtalan variációját vonultatták fel. A városok versenyében visszatérô momentumok, fejlesztési elemek ismétlôdtek, mint az anyagi infrastruktúra javítása és a városi revitalizáció, a kulturális élet erôsítése, a szegénység enyhítése a foglalkoztatás növelésével, illetve a turizmus erôsítésével. Az évek során nyilvánvalóvá vált, hogy Európa Kulturális Fôvárosának lenni felbecsülhetetlen marketinglehetôség a városok számára imázsuk javítására. Lehetôséget ad a különbözô hatóságok, szereplôk és a városi lakosság közötti párbeszédek fokozására, egy közös cél felé való evezésre. Mindemellett a városok a kultúrát, a kulturális örökséget és a múvészeteket mintegy keretként használják egyediségük kifejezésére (Ooi-Hakanson-Lacava, 2014). Megjegyzendó, hogy az EKF-projektet az egyik legsikeresebb kulturális projektnek tartják az európai projektek között (PalmerRichards, 2007).

E sikeres és izgalmas projektre pályázni szándékozó városoknak elsô lépésként kézbe kell venniük az Európa Kulturális Fôvárosa projekthez kapcsolódó útmutatót, mely magyarázza a lépések folyamatát és a kritériumokat. A dokumentum célja, hogy a városok megfontolják jelentkezésüket, és elókészítsék a pályázatukat. Ezenfelül további két dokumentumot kell figyelembe venni a pályázni szándékozóknak (EC, 2018): egyrészt a határozatot, amely mint hivatalos, jogi dokumentum az EKF-projekt alapját képezi. Habár jogi dokumentumról beszélünk, az mégis könnyen érthetô és elérhetô az Európai Unió valamennyi hivatalos nyelvén. A harmadik dokumentum a kérdések listája, amelyekre válaszokat várnak a pályázó városoktól. A kérdések támaszkodnak a határozatra. A jelölt városok ezt a kérdôívet töltik ki pályázati anyagukban. ${ }^{1}$

A jövóbeli Európa Kulturális Fơvárosa címre pályázóknak a terveikben, elképzeléseikben, akcióikban az EKF-kezdeményezés céljait kell szem elôtt tartaniuk (1. ábra). 


\section{1. ábra: Az Európa Kulturális Fớvárosa kezdeményezés céljai}

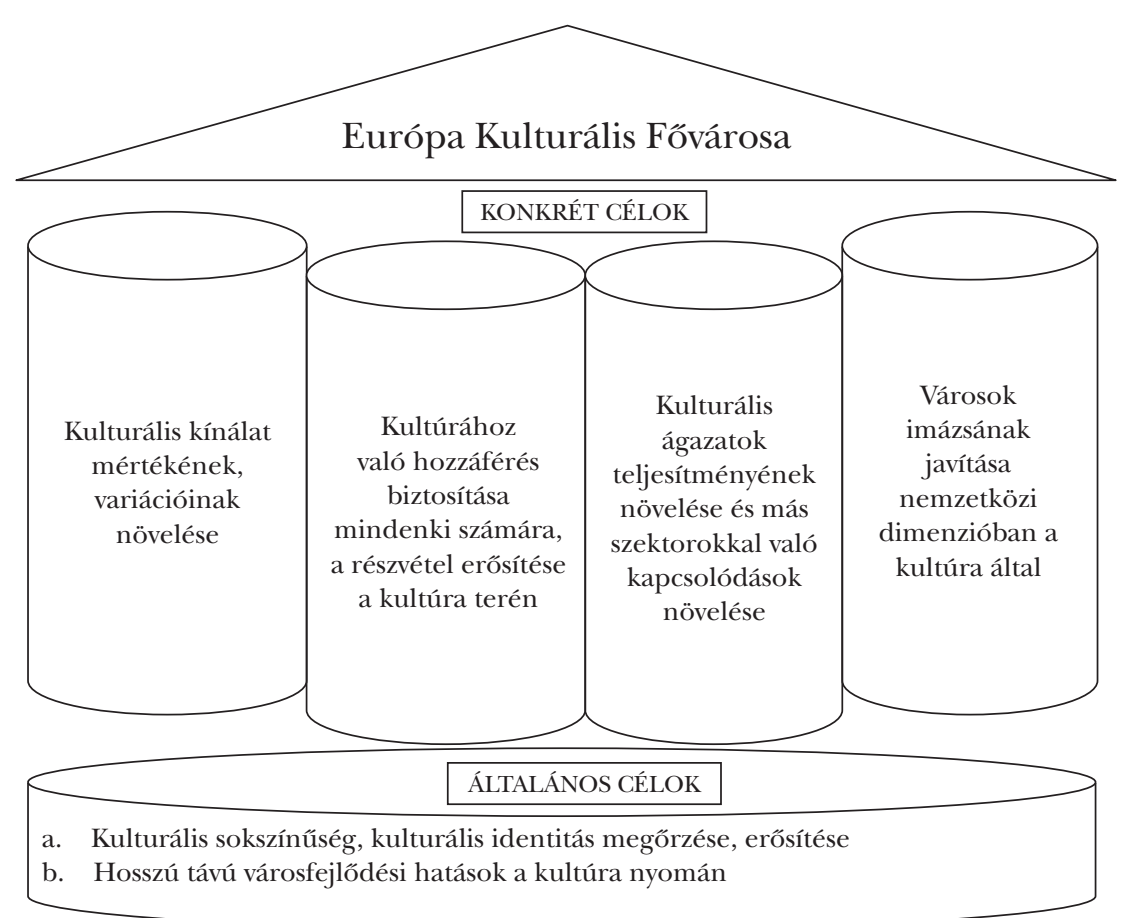

Forrás: Saját szerkesztés a 445/2014/EU határozat alapján

Az EKF-projekt általános céljai mintegy talapzatát képezik a programnak, melyek alapvetően az európai kulturális sokszínúség feltárását, a kulturális identitás megôrzését és erôsítését, valamint a hosszú távú városfejlődési hatások kultúra általi generálását jelentik. Az általános célok mellett konkrét célok mint oszlopok is felsorakoznak az EKF-projekt keretében. A városoknak meg kell célozniuk a kulturális kínálatuk mértékének, sokszínúségének növelését, mindenki számára lehetôvé kell tenniük a kultúrához való hozzáférést, erôsíteniük kell a lakosság részvételét a kulturális életben, elő kell segíteniük a kulturális ágazatok, a kulturális és kreatív ipar teljesítményének fokozását, valamint a kapcsolódását más szektorokkal, végül a városról formált kép javulását kell elérni, méghozzá nemzetközi dimenzióban.

\section{A PÉCSI TAPASZTALAT}

Pécs, Magyarország eddigi egyetlen megvalósult Európa Kulturális Fôvárosa, tapasztalati alapot jelent a nyertes magyar város számára, ezért érdemes levonni a Pécsen megrendezett eseménysorozat tanulságait. Pécs azért is különleges példa, mivel a bányászata és nehézipara leépülése komoly gazdasági nehézségeket okozott, és a város 
vezetôi úgy vélték, a válságból a kulturális ipar fejlesztése és az EKF által elinduló, új fejlôdési pálya mozdíthatja ki (Tuka-Glied, 2014). A magas színvonalú pécsi pályázat, mely A határtalan város címet viselte, a kulturális fejlesztések mellett foglalkozott a városimázs olyan irányú megváltoztatásával, amely a turisták és a városlakók Pécsrôl alkotott képét formálja, és teszi a várost vonzóvá akár a tôkebefektetôk számára is (Takáts, 2007). A pályázat olyan fogalmakat, kulcsszavakat használt, amelyek szinkronban álltak a városfejlesztéssel foglalkozó, nemzetközi mainstream által elfogadott fogalomkészlettel, emellett a pályázat meghatározta azokat az akciókat, amelyek a kultúraalapú városfejlesztés keretén belül vihetơk végbe (Faragó, 2010).

Pécsen az EKF-program hatása azonban ellentmondásosnak tekinthetô, sok nehézség befolyásolta a projekt eredményeit. Többek között az ún. kiszorító hatás miatt, az EKF-re hivatkozva a város elesett egyéb központi támogatásoktól. A koncepció is adós maradt abban, hogy a város tényleges gazdasági állapotát csak kismértékben vette számításba, az elvándorlás, a társadalmi és térbeli szegregáció kérdéseit figyelmen kívül hagyták. Figyelmeztetés Veszprém számára az is, hogy nem hagyható a város más tervdokumentumainak érvényvesztése, leértékelődése, mint ahogy az történt Pécsett (Faragó, 2011). A tanulságokat levonva kell a következô magyar Európa Kulturális Fóvárosának sikeres programot megvalósítania, melyhez a Pécs EKF-programjával foglalkozó, a projekt vizsgálatát sok nézôpontból megközelítô számtalan kutatás és tanulmány ad tudományos alapot. Többek között idesorolhatók a kormányzási metodikák, a többszintú kormányzás nézôpontjából (Pálné Kovács, 2010; 2013; 2014; Grünhut, 2013), a városfejlődés szempontjából (Faragó, 2010; 2011; 2012), a civilek véleményének feltérképezéséből (Glied, 2014), gazdasági vonatkozások tekintetében (Schmidt, 2014), a pécsi kulturális intézmények funkciói alakulásának vizsgálatából (Egry, 2010) készült tanulmányok. A 2018 decemberében meghozott döntés szerint nyertes városnak, Veszprémnek érdemes ezen kutatások szövevényes erdején végigbarangolni.

\section{A PÁlyázó VÁrosoK helyzeTFELTÁrásA, FEJLôdéSI FOLYAMATAI}

Az elemzések, tanulmányok feldolgozása nyomán - melyek akár Pécs, akár bármelyik korábbi címbirtokos EKF-projektjérôl készült - megfogalmazódik a kérdés, hogy valójában mikor tekinthetô az EKF-projekt sikeresnek? A múvészeti és kulturális tartalom, vagyis a kulturális programok sikeressége - a zavartalan lebonyolításon át a magas látogatószámon keresztül a minôségi elvárásokig - csak egy része az EKF sikerességi kritériumainak. Az EKF sikere a város sikere kell hogy legyen, vagyis végül is a városnak kell sikeressé válnia az EKF jótékony hatásainak kiaknázásával, mely sokkal mélyebb tartalmakat és dimenziókat jelent. A városfejlódés szerves részeként kell értelmezni, annak bonyolult és magas fokú ismereteket megkívánó folyamatába kell beleilleszteni. Ehhez azonban ismerni kell a város belsố természetét, adottságait, történeti fejlődését, társadalmi, szociális helyzetét, gazdaságszerkezeti képét. Az elmúlt évek magyarországi városkutatásai biztos alapot nyújtanak abban, hogy lássuk a városok ezen szerves fejlődési folyamatait. A területi tóke kutatása, egy-egy területi entitás, város egyediségét, 
Morvay Szabolcs: Európa Kulturális Fốvárosa projekt: A veszprémi, gyôri és debreceni...

sajátos meghatározó tényezôit, fejlődésének erőforrásait kutató vizsgálódás teret nyert az utóbbi idóben.

Rechnitzer János A területi tőke a városfejlödésben. A Gyốr-kód címú munkája átfogó, részletekben gazdag képet ad Győr fejlődése mozgatórugóinak a megértéséhez. A gazdasági, társadalmi és kulturális tôke feltárását végezte el a magyar modernizáció egyik sikeres városában. Gyôrben a nyolcvanas évektôl a kulturális tôke kibontakozását láthatjuk, a kulturális kínálat bóvülését, a kulturális funkciók szélesedését. A kilencvenes évek átmeneti idôszaka lendületet hozott ebben a folyamatban, számos kulturális kezdeményezés született ebben a korszakban. A jótékony kulturális dinamikához hozzájárult a város múvészetet pártoló polgármestere, Kolozsváry Ernô, aki kiemelten támogatta a város kulturális intézményeit, és indította el új intézmények alapítását. Az ezredforduló után tovább folytatódtak a kezdeményezések, a város a táncmúvészetben kiemelt pozícióhoz jutott (Győri Táncmúvészeti Biennálé), megalakult a Gyôri Fesztivál és Rendezvényszervezó Iroda (ma Gyôri Múvészeti és Fesztiválközpont), valamint 2010-ben a „Kultúra Városa” címmel lett fényesebb a város. Ez a töretlen kulturális fejlődés tetôződhetett volna be az Európa Kulturális Fơvárosa cím elnyerésével 2023ban (Rechnitzer, 2016). Ráadásul a városfejlesztési dokumentumok, az Audi Hungária kiemelkedô múvészetpártoló, szponzorációs tevékenysége és a Modern Városok Program kapcsolódó fejlesztései is jó alapot jelentettek a gyôri pályázatnak (Fekete, 2018b; Fekete-Rechnitzer, 2019).

A jótékony folyamatok hatással voltak a város külsố megítélésére, Gyôr turizmusa az elmúlt években fokozatosan javuló tendenciát mutat. Erôs az üzleti turizmus, fóként a városhoz kötődô autóipari cégek miatt, jelentôs a szállodák hétköznapi igénybevétele, illetve az átlagos itt-tartózkodási idóben is javulás érezhetô. Izgalmas, hogy a városhoz szimbólumok (városháza, vaskakas, folyók, Audi) kapcsolódnak, melyeket a lakosok és az odalátogatók is egyértelmúen Gyôrhöz kötnek. Ugyanakkor a város imázsát alakították a barokk belváros, a természeti környezet és az iparhoz kapcsolható objektumok (Tóthné Kardos, 2016). Gyôr területi tôkéjét kifejezetten gazdasági vonatkozásban vizsgálva, olyan tulajdonosi hálózatokat, együttmúködéseket tártak fel, fơként a jármúipari szegmensben, amelyek innovációs funkcióként képesek szolgálni a város fejlődését, illetve a tudásteremtés nagymértékú folyamatai érhetôk tetten Gyôr városában (Czakó-Dóry, 2016).

Azonban a városfejlődést annak kormányzási metodikája is erôteljesen befolyásolja. Győrben a modern nagyvárosi kormányzás a közigazgatási szemléleten túlmutatva már gazdaságfejlesztési irányokat jelöl ki. Mi sem bizonyítja ezt jobban, mint azok a társulások, szervezetek (Gyôri Jármúipari Életpálya Modell, Gyôr Térség Foglalkoztatási Egyezmény, Gyôri Helyi Akciócsoport és Arrabona EGTC), amelyek az utóbbi években gazdaságfejlesztési célzattal alakultak. A szemlélet elvi mozaikdarabjai a város-régió fókusz, a részvétel, fenntarthatóság, a szektorspecifikus jelleg (Fekete, 2018a). Az Európa Kulturális Fôvárosa projekt számos célkitúzésével találhatunk párhuzamot a fentiekból kiemelt Gyôri Helyi Akciócsoport közösségvezérelt helyi fejlesztési munkájában, a CLLD-programban, melynek keretében az Akciócsoport a kulturális tartalmú és közösségi kapacitás mentén helyi fejlesztési irányokat jelöl ki, gondolva itt a kulturális és 
közösségi terek infrastruktúrájának fejlesztésére, valamint a helyi közösségfejlesztésre. A város voltaképpen az EKF számos prioritásában már napjainkban az élen jár. ${ }^{2}$

Veszprém városa a veszprémi nagyvárosi településegyüttes központi települése. A „Királynék városa” a Közép-Dunántúl régióban található, a Bakony és a Balaton között fekszik (KSH, 2014). A város népessége 61721 fố (KSH, 2013b), azonban a lakosság Veszprém 50 km-es körzetében 600 ezer foóre rúg. A város gazdaságában meghatározó szektor az autóipar, számos autóipari gyártó és beszállító cég múködik Veszprémben, ezek közül kiemelhetô a Continental Automotive Hungary Kft., amely háromezer fót foglalkoztat. Emellett fontos ágazat a városban az elektronika, a gépipar és az élelmiszeripar. A rendszerváltás Veszprém gazdaságában is szerkezeti átalakításokat hozott, amelynek következtében a mezőgazdaság háttérbe szorult. A szolgáltató szektor a legjelentôsebb ágazat a városban, a gazdasági szerkezet 65\%-át a szolgáltatás adja, az ipar 35\%-os aránya mellett. Mindemellett elmondható, hogy Veszprém városában hétezer vállalkozás múködik. A munkanélküliségi ráta mérsékeltnek tekinthetô, 5-6\% körül mozog. Kiemelendó a város oktatási kapacitása is: három felsôoktatási intézménnyel rendelkezik, emellett 19 középfokú és 11 közoktatási intézmény múködik Veszprémben. A legjelentôsebb oktatási intézmény a Pannon Egyetem. ${ }^{3}$

A város kulturális életében az elmúlt két évtized során számos változás zajlott le, mindez érintette az intézményeket, szervezeteket és a civil szférát. A kulturális magánszervezôdés felerôsödött, aktívabbá vált. Emellett a város kulturális kínálata iránt is megnövekedett a helyi és külföldi érdeklôdés. Jelentôsen erôsödött a fesztiválok és nagyrendezvények szerepe. A kultúra és a turizmus a város döntéshozóinak és aktorainak gondolkodásában összefonódott. A közmúvelődést szolgáló intézményrendszer kapacitása az elmúlt években jelentôsen bôvült. A város egyházi szerepköre is jelentôs, amely mintegy ezeréves múltra tekint vissza. ${ }^{4}$

Debrecen hazánk második legnagyobb városa - a 2011-es népszámlálás szerint 211320 fő - és régióközpont (KSH, 2013a). Gazdasági, kereskedelmi, oktatási, egészségügyi, kulturális funkcióinak hatása túlnyúlik a határon. A legkiemelkedôbb szerepkör az oktatás Debrecen esetében, mely történelmi hagyományokban gyökerezik, ezen belül is fôképpen a felsôoktatás jelentôs. A Debreceni Egyetem mellett több felsôfokú intézmény kimagasló hallgatószámmal bír, megtalálhatóak a nemzetközi léptékben is vonzó képzések. Kutatóintézetek is múködnek a városban (MTA Atomki). A város kulturális központ, kiemelkedó intézményei - Kölcsey Központ, MODEM, Fônix Csarnok - országos viszonylatban is elsôrangúak. Mindemellett egyházi központ is. A város vonzerejét, idegenforgalmi potenciálját a kulturális rendezvénykínálata is erôsíti, illetve szállodai kapacitásai, mivel nagy számban rendelkezik ötcsillagos szállodával, négycsillagos szállodával, panziókkal, egyéb szálláshelyekkel. Konferencia-, gyógy- és sportturizmussal is büszkélkedhet. ${ }^{5}$

\section{PÁlyázati A MB B́́CIÓK}

Győr EKF-szlogenje - „Enjoy the Flow!” - a koncepció tematikája is egyben, vagyis az áramlás adta a város témáját a pályázathoz. A tematika jelentôsége abban rejlik, hogy 
mintegy oka is, forrása is a szándéknak, célnak, hogy a város kulturális fơvárossá váljon. Gyốr példát akart mutatni Európának azzal, hogy mindig is áramlási ösvények csomópontjaként állt helyt a történelemben, és tapasztalta azt a jelenséget, mellyel Európa most zavartan néz szembe. Az áramlásnak rendkívüli a kulturális hatása, kulturális vonatkozása. Győr képes volt építő módon felhasználni az áramlások kulturális kihatásait. Ez a múltbeli tudás példaértékú, és fontos üzenettel bír Európa számára. Emellett a város saját földrajzi elhelyezkedésére is reflektálni akart, a belőle fakadó előnyök új elemeit kívánta integrálni a projekt által. Európa kultúrtörténetének digitalizálása és a jelenkori áramlások mind-mind új korszakot hoznak a kontinensen, egyszerre kell tudatosan rögzíteni saját múltunkat, és megismerni egy másik kultúrát. Ebben tudott volna Gyớr nagy szerepet játszani földrajzi pozíciója, történelme és ambíciói nyomán. Azonban a koncepció kialakítása során a problémák feltárása is megtörtént, legfơképpen a kulturális és kreatív szakemberek elvándorlása jelent gondot, mely problémát az EKF-pályázat igyekezett kezelni.

Veszprém saját pályázatában Európára fókuszál, európai várossá kíván válni, a Balaton által európai találkozóponttá. A pályázat bevezetésének kissé borúlátó hangvételére válaszul, az EKF-projekt mintegy megoldásként jelenik meg a magát kisvárosnak tituláló település és régió szezonális függésének, kiüresedésének gondjára. A város kireked két gazdasági tengelybôl is, a Bécs-Pozsony-Győr- és Budapest-Székesfehérvár-tengely között elszigetelődött térség magára maradt. A pályázat egyfajta bizonyítási vágy is, hogy Veszprém és a balatoni térség képes izgalmas, európai és kulturális területen vezetô hellyé válni. Ugyanakkor két ellentétre is rámutat: az egyik a tôsgyökeres veszprémiek és a múlt század utolsó évtizedeiben betelepültek között húzódó, gondolkodásmódbeli különbség, a másik pedig Veszprém vallási központ volta és vallási intézményeinek helykeresése a modernné vált világban. Ezek az ellentétek diszharmóniát teremtenek, az EKF-cím hozzájárulhat ezen ellentétek feloldásához. Emellett jellemzô a városközpont kiüresedése, elsôsorban a fesztiválszezon elmúltával, ezért új funkciók, új kulturális tartalmak szükségesek, a másik probléma a közönség passzivitása, ezért a város lakóit is mozgósítani kívánják a kultúra terén.

Debrecen a pályázat bevezetôjében történelmi kitekintést tesz, saját múltjában keres gyökereket a pályázati szándék magyarázatához, kiemelve, hogy az elmúlt két évszázadban kétszer is fôvárosként játszott jelentôs szerepet az ország történelmében. Ugyanakkor a városra jellemzô kettôsséget állítja a középpontba: Debrecen egyszerre volt mezőgazdasági központ, a kétkezi munka, a céhes ipar és jelenünkben az ipari parkokban tevékenykedő cégek otthona, illetve a szellemiség, tudás, a polgári haladó eszmék fellegvára. A kettósség mára halványulni látszik, a gyakorlati ismeretek, gyakorlati munka ereje, tere szúkül. A város célja az, hogy a folytonos megújulás egyszerre legyen jelen a hagyományok, a múltban csörgedező gyakorlati tudás megóvásával. Az Európa Kulturális Fóvárosa cím esetükben voltaképpen e központi gondolat köré épült, az errôl való párbeszéd eszközeként értékelték. Kiemelendő, hogy a kulturális szektorról mint új gazdasági ágról Debrecenben gazdaságfejlesztési kérdésként, egyfajta katalizátorként is gondolkodtak az EKF kapcsán, bár erre a bevezetés csupán egy rövid bekezdésben tér ki. Debrecen a pályázatban említést tett geopolitikai helyzetérôl, Ukrajnát és a Nyugat-Balkánt jelölte meg kapcsolódási pontként. 


\section{Kulturális PROFIL}

Gyôr kulturális profilját a történelem formálta, a múlt gazdag szellemi és kulturális örökséget hagyományozott a városra. A korok átruházták legfontosabb értékeiket, így a barokk belváros, az ipari hagyományok, valamint a Pannon-örökség mint sajátos szellemi karakter máig meghatározó. Barokk stílusú épületekben, múemlékekben gazdag, és a város elkötelezett ezen örökség ápolásában, hasznosításában. Győr kulturális szférájának meghatározó eleme az egyeteme, mely látványos fejlódésen ment keresztül az elmúlt évtizedben. A felsőfokú képzés mellett jelen van a kiemelkedô, európai színvonalú középfokú oktatási bázis is. Fontos hangsúlyozni a múvészeti képzés jelenlétét a városban, a zene felsőfokú szinten is elérhetô az oktatási palettán, de balett és képzốmûvészet oktatása is zajlik középfokon. Gyốr számos múvészeti intézmény révén ad otthont a múvészeteknek. Mútárgygyújteményekben gazdag, irodalmi folyóirattal büszkélkedik, és kétségtelenül a hazai táncmúvészet központjává vált. Azonban nem hagyható ki a felsorolásból a tudományos múhelymunka sem, kutatóközpontok biztosítják a múszaki és társadalomtudományi kutatások folyamatos zajlását.

Veszprém a pályázatában önmagát Magyarország egyik legszebb városának titulálja, és meghatározó kulturális jelentôséget tulajdonít magának, kiemelve történelmi emlékeit. A kulturális potenciálban a hangsúly a fesztiválokra kerül: a város elsôsorban zenei fesztiváloknak ad otthont, de a kortárs múvészettel való kapcsolat is jelentôs, már-már országos központjává vált a modern képzőmúvészeteknek. A múvészeti intézmények nagy számban vannak jelen Veszprémben. A város büszke a VeszprémFest rendezvényre, az Utcazene Fesztiválra, az Auer Hegedúfesztiválra. Az oktatási struktúra élén két egyetem is áll: a Pannon Egyetem, illetve az Érseki Hittudományi Fóiskola. A pályázat kiemeli a Pannon Egyetemen folyó kutatás-fejlesztési munkát. Fókuszpontba kerül a Hangvilla névre keresztelt multifunkcionális közösségi tér, mely a kulturális élet kiemelt helyszíne. A veszprémi Várhegy, bár értékes kiállításokat tár a közönsége elé, elhelyezkedése miatt némileg kiesik a lakosság mozgásteréből. A kulturális potenciál bemutatásának keretében a nehézségeket is bemutatva, a városban élốknek a kultúra irányában mutatkozó passzivitása mint negatívum jelenik meg. E csorba kiküszöbölése érdekében a város újra kívánja gondolni a közönségfejlesztési stratégiáját.

Debrecen a pályázatában úgy értékeli kulturális potenciálját, hogy az 100-150 kmes körzetben is kihat. A szokásos városi kulturális intézményeken túl országos jelentôségú intézményeket is megjelöl, mint például a MODEM, mely kortárs múvészeti központként az ország legnagyobb vidéki kiállítótere. Mind a Csokonai Színház, mind a Kodály Filharmonikusok nemzeti kategória alá sorolandók. Múzeumát, bábszínházát, az Agóra Tudományos Élményközpontot emeli ki a pályázat, melyek mind jelentôs intézmények országos viszonylatban is. Két terv a pályázatban a kulturális infrastruktúra fejlesztésérôl árulkodik, az elmúlt évtizedben a Fônix Terv és az Új Fônix Terv keretében korszerúsítették a kulturális intézményeket. Debrecen városvezetése évról évre emeli a költségvetésben a kulturális szférára fordított keretet, amelyben az állami hozzájárulás 33\%. Mintegy kétszáz kulturális tevékenységet folytató civil szervezet múködik a városban. 
Bírálatként jelenik meg az értékelésben, hogy a kulturális tartalomfejlesztés elmaradt az infrastrukturális fejlesztés mögött, illetve a város konzervatívnak titulálja saját kultúrafelfogását, értve ez alatt azt, hogy a város közönsége nehezebben fogad be kortárs, modern tartalmakat. Debrecen vezetése úgy véli, voltaképpen egy kisváros kulturális életéhez hasonlítható a debreceni kultúra világa, és csakis külsố forrásból való merítkezés révén látja javíthatónak a jelenlegi állapotot, ugyanis kreatív és tehetséges emberek számára nincsenek motivációs, megtartó tényezôk a városban. A város gazdasági szerkezetében jelentéktelenek a kulturális és kreatív gazdaság pillérei, az irányító szereplők pedig idegenkednek a változástól. Hiányzik a kulturális karakter, profil és identitás. A fiatalok érdektelenek a város kulturális és leginkább a múzeumi negyed intézményei iránt. A legfőbb vonzerôvel bíró, többfunkciós Nagyerdő központ, élménypark, vigalmi negyed is negatív hatást fejt ki, épp a pozitív tulajdonságai révén: elszívja a belvárosból a szórakozni vágyókat. A problémák megoldását stratégiai szinten kezelik, illetooleg az Európa Kulturális Fôvárosa címet katalizátorként hasznosították volna.

\section{REGIONÁLIS DIMENZIÓ}

A gyôri pályázat épített a régiós partnerekre, kedvezó földrajzi helyzetéból következôen három fốváros is kapcsolati alapokat jelentett volna. De nemcsak a fôvárosok múvészeti elitje és potenciálja jelentette volna a környező térség bevonását a projektbe. A projekt során a szakrális és kulturális örökség elemei, értékei kerültek előtérbe a Pannonhalmi Bencés Főapátsággal való közös szerepvállalás keretében, de ugyanúgy a fertôdi Esterházy-kastély vagy éppen a galántai, kismartoni, nagycenki kastély, illetve Mosonmagyaróvár és Dunaszerdahely is izgalmas helyszínei lettek volna a projektnek, melyek turisztikai és környezeti megújítási törekvései már most is a város általános céljai között szerepelnek. Emellett a Szigetköz és Csallóköz vidékét sem hagyta figyelmen kívül a város.

Veszprém pályázatában kiemeli, hogy a főszerepló a projekt során maga Veszprém városa. A vezetôség túlnyomórészt a városba tervezi a beruházások és programok lebonyolítását. Természetesen a Balaton és térsége kihagyhatatlan részét képezi a programnak. A helyszínek második pillére a Balaton-felvidék és Veszprém közvetlen környéke, a harmadik pedig a balatoni üdülőkörzet lesz.

Debrecen is gondolt a környezô településeire, hangsúlyozottan szerepel Hortobágy település mellett a Hortobágyi Nemzeti Park szerepe is. De tágabb területi dimenzióban is gondolkodtak, méghozzá az északkeleti megyék és települések részét képezték volna a programsorozatnak. Nyíregyháza mint szomszéd megyeszékhely stratégiai megállapodás alapján is kiemelt szerepet kapott, illetőleg Miskolc és Tokaj - bár pályázati ambíciójukról letettek - részt vállaltak volna a projekt szervezésében, megvalósításában. Azonban Debrecen is kitekintett az országhatáron túlra, Margitta, Szatmárudvari, valamint Nagyvárad jelentik a határon túli kapcsolatokat. Debrecen célként fogalmazta meg Ukrajna európai integrációjának segítését, a hálózatépítés folyamatának gondozását. Románia északnyugati városaival kapcsolatban álltak, illetve kelet-szlovákiai városokkal, Kassával és Eperjessel egyeztettek. 


\section{A PROGRAMOK KONGEPCIÓI}

Győr koncepciójának gondolati magja az áramlás volt, utalva a természeti elem, a víz áramlására. Hiszen a Duna, mely számos országot érint, Győrön keresztül folyik, öszszekötve ezzel a várost számos értékes európai partnerrel. A szlogen utal ugyanakkor a 21. század elsöprố jelentôségú elemének, az információnak az áramlására, de ugyanúgy az egyre természetesebbé váló új közegben, a virtuális térben való információ- és tudásáramlásra, vagy az alkotás, a kreatív megnyilvánulások során tapasztalt élményre.

Veszprém a párbeszédre kötelezi el magát a projekt során, mely párbeszéd a lakosok és múvészek közötti, valamint Európával való párbeszédet jelenti. Majd a gondolati mag, a párbeszéd motívum átadja a helyét a „túllépni” kifejezés gondolatvilágának. A kissé melankolikus hangvételú folytatásban felemlegeti a város kulturális kudarcait, és szinte egyetlen segélykiáltásba tömöríti a jövőbeni elképzeléseket. Az EKF-cím mint gyutacs a dinamitban jelenik meg ebben a gondolati körben. Három kifejezés is felbukkan, melyekkel a város saját magát jellemzi: provincializmus, kishitúség, közönyösség, mely tulajdonságok legyőzésében elkötelezett Veszprém. Az őszinte problémafeltárás nem egyedi jelenség, az EKF-pályázatoknál gyakran megfigyelhetô.

Debrecen a pályázatában a koncepció ecsetelésében ismét a szellemi és gyakorlati tudás ellentétpárját boncolgatja. Aggodalmát fejezi ki a „kezünkkel való tudás” fokozatos háttérbe szorulásáért, mely a digitális forradalom következménye lehet. Megismétli, a bevezetôben leírtakhoz hasonlóan, hogy Debrecen mind a gyakorlati, mind az elméleti tudás otthona, de további erôsségeket is felsorakoztat, ilyenek: az elsố hazai nyomda, Debrecen iskolái, a magyar kultúratörténet nagyjainak kötődése Debrecenhez, a Debreceni Egyetem dinamikus fejlődése, vagy éppen jelentôs irodalmi folyóirata, az Alföld. A pályázat hangsúlyozza, hogy a város a már meglévô értékeket, hagyományokat kívánja dinamizálni, mozgósítani a projekt segítségével, kulturális kapacitását szeretné bővíteni, polgárait aktívvá tenni, a gazdaság fejlődését a kultúra fejlődésével szinkronba állítani, illetôleg regionális szinten mélyíteni a kapcsolatait. Debrecen kulturális megújulása, kulturális turizmuson alapuló fejlôdési lehetôségek számbavétele, a lakosság bevonása a programok alakításába, kulturális modell szerepbe való kerülés mint kulcsgondolatok emelhetôek ki a koncepcióból. A pályázattal szemben kritikaként megfogalmazható, hogy a koncepció inkább esszé jellegú, elsôsorban különbözô - kultúrához kapcsolódó - témák fejtegetése, illetve a város tulajdonképpen kulturális sikereinek, múltjában megjelenô eredményeinek bemutatása, maga a koncepció - célok, elképzelések strukturált számbavétele - ebbe a szövevényes, mindenre kiterjedô fejtegetésbe ágyazódik.

\section{Hosszú TÁVÚ STRATÉGIA ÉS HATÁSOK}

A hosszú távú stratégia ebben a vonatkozásban azt jelenti, hogy az EKF-cím annak a városnak ítélhetô oda, amely értékelhetô, releváns kulturális stratégiával rendelkezik, mely akkor is érvényes, ha a város mégsem nyeri el a címet. Vagyis a kulturális beruházások, tevékenységek a város költségvetésének konkrét elemei, számított tényezôi, a 
kulturális építkezése átgondolt, ambíciói eredetiek, tehát a város fenntartható kulturális fejlesztést teljesít. További elvárás, illetve iránymutatás, hogy a gazdaság új, utóbbi másfél évtizedben kibontakozó, izgalmas szektorai, a kulturális és kreatív gazdaság tudatos építése, meghonosítása része legyen a város stratégiájának.

Gyôr a pályázatában bemutatta a határozatokat, melyek húen bizonyítják Gyôr Megyei Jogú Város Önkormányzatának elkötelezôdését a fentiek tekintetében, illetve a város határozattal elfogadott kulturális koncepcióval rendelkezik. A koncepcióban megtalálhatóak a prioritások, amelyekkel Gyôr folyamatosan segíti a kulturális tevékenységek, intézmények megújulását. Nemcsak a lakosság kulturális igényeit elégíti ki a város, hanem nemzetközi viszonylatban is fenn kíván lenni a kulturális, idegenforgalmi „térképen”. A kulturális koncepció kapcsolódik a város különbözô gazdasági és civil szektoraihoz, összhangban van a tágabb gazdasági és társadalmi feladatokkal, törekvésekkel. A kulturális koncepció az infrastrukturális fejlesztések mellett szervezeti és finanszírozási célokat is meghatároz. A beruházásokat konkrét, országos szintú program, annak finanszírozása támasztja alá, a Modern Városok Program finanszírozási alapot nyújt a kulturális beruházásokhoz. A koncepció magában foglalja a terveket, amelyek szavatolták a 2023-as évet követố években felmerüló fenntartási követelmények zökkenômentes kezelését. A hosszú távú kulturális, szociális és gazdasági hatások közül a pályázat a legfontosabbnak a gyôri polgárok kultúrához és egymáshoz való kötődésének erôsítését tartja. Európa régiói, illetôleg a kultúra és kreatív területek szektorai felé közvetített üzenetként Gyôr megfogalmazta a kulturális kezdeményezések közös megvalósításának lehetôségét, mely inspirálóan hathat a fiatalok kultúrához való viszonyára.

Veszprém legújabb kulturális stratégiáját 2017 decemberében fogadták el. A stratégia a SWOT-analízis metódusát tükrözve, a város erôsségeit állítja elôtérbe, azokra épít: fesztiváljaira, a balatoni térségre, illetve színvonalas kulturális helyszínekre. Ugyanakkor gyengeségeit is bevallja, azokra intézkedéseket, javítási mechanizmusokat irányoz elô. Céljai tematikák köré épülnek, amelyek kulcsszavai: a versenyképesség, örökségvédelem, kreatív ipar, turizmusgazdaság, közösségépítés a kultúra segítségével, illetve múvészeti képzés és közönségfejlesztés. A pályázat hangsúlyozza, hogy az EKF-projekt csak egy része a város 2030-ig szóló kulturális stratégiájának, igaz, meghatározó szerepet játszik abban, hiszen erőforrásokat, marketinglehetôséget és önbizalmuk megerôsödését várják a cím megszerzésétől. A veszprémi Aranyosvölgyben kreatív ipari központot kívánnak kialakítani, fơként a kézmúvesipar felkarolása céljából. A belvárosban kulturális negyedet szándékoznak építeni, mely nagyszabású színházfelújítást is magában foglal. Emellett felújítják a Veszprém Arénát mint rendezvénytért. Az EKF-projekt a város stratégiájában különféle szerepekkel, funkciókkal jelenik meg, mint például a problémamegoldások európai nézópontból való keresése, partnerek tapasztalatainak adaptálása, kulturális szövetség kialakítása révén. Az EKF a tervezett kulturális tereket programokkal, tartalommal tölti majd fel, és kulturális szakembereket, szereplóket vonz Veszprémbe.

Debrecen a 2018-2030-as időszakra szóló kulturális stratégiáját szintén 2017 decemberében fogadta el. A stratégia hangsúlyozottan mind a gazdasági, mind a turisz- 
tikai tervekkel összhangban áll, illetôleg annak a felelôsségnek a tudatában készült, hogy Debrecen fontos régiós központ, emellett figyelmet szentel a határon túli, hoszszú távú kapcsolatoknak is. A kulturális stratégia rögzíti, hogy a város évente emeli kulturális kiadásait, mely 2023-ra a költségvetés 11\%-át éri el. Debrecen város Főnix Terv elnevezésú gazdaságfejlesztési programjában kulturális beruházások is szerepeltek, az Új Főnix Terv pedig szintén hozzájárul a kulturális infrastruktúra fejlesztéséhez. A kulturális stratégia céljai között szerepelnek a hagyományok felélesztése, a város kulturális identitásának újragondolása, a kreatív ipar meghonosítása, illetve a városi brand, városimázs építése. A kultúrához való egyenlô hozzáférés elve alapján új kulturális központok építését irányozzák elô a belvárostól távolabb esố településrészeken. A stratégia hangsúlyt fektet a civilek bevonására a kultúra alakításába. Szervezetfejlesztési elképzelések között jó ötlet az intézmények részérôl a közfeladat ellátásán túli projektmunkák vállalása, illetve a menedzserszemlélet a források bevonásában. Vélhetôleg az elkényelmesedésból, a sztenderd programok szervezéséból való kimozdulásnak egy jó eszköze lehet a kezdeményezés.

A stratégia és az EKF-pályázat közötti kapcsolat egyértelmú, az EKF mint gyorsító mechanizmus szolgálta volna a stratégia céljainak megvalósítását. Debrecen tíz tervezett kulturális nagyberuházást foglalt bele kulturális stratégiájába, szándékai között szerepelt ezek túlnyomó részének 2023-ig történô megvalósítása. A pályázat az EKF hosszú távú hatásai között emeli ki a nemzetközi kommunikáció fejlôdését a kultúra területén, illetve európai szinten látható városi vagy intézményi brandek kialakítását. A stratégia alapján a város magabiztosan kívánja használni a kultúra városfejlesztô erejét, mely által kulturális innovációk bontakoznának ki, kialakulna egyfajta kulturális tudatosság, mely megjelenne a köztereken, utcákon különbözô formákban, különbözô eszközök által. A stratégia szerint a kulturális intézmények ún. supervisori funkcióval, alulról jövô civil kezdeményezéseket karolnának fel, civilek és szakemberek közösen formálnák a város kulturális életét. A város kulturálisan elhanyagoltabb területein is megjelenne a kulturális pezsgés, a kultúrához való hozzáférés esélye. A lakosság aktív szerepe erôsödne a kultúra terén. Gazdasági hatásként kívánják elérni a kreatív ipar és turizmus erôsödését, a vendégéjszakák számának növekedését, illetve a kulturális szektor kínálatának és a kulturális fogyasztásnak a serkentését.

\section{Kulturális ÉS MÚVÉSZETI TARTALOM}

Gyơr múvészeti terve három programcsomagba tömörült, „Út”, „Város” és „Párbeszéd” programcsomagba. A 2023-at megelôzô, felvezetó évek alatt, tehát már 2018-tól futottak volna a három témakör alá rendezett programok. Az elsô programcsomag a Gyôrön keresztülfutó, európai utakból fakadó tapasztalatokat fejezi ki, kulturális kontextusban. A tervezett cél volt, hogy ezek az utak az EKF-program kapcsán elvezessék Gyơrbe a kulturális élményekre vágyó utazókat. Konkrét program lett volna ezen belül a „Tematikus utak”, melyek révén ismerhetôk meg, járhatók végig azok a történelmi folyamatok, amelyek Győr és az egész térség alakulását befolyásolták. A „Város” témakör kreatív és kulturális pezsgést kívánt fellobbantani Gyôrben, a fiatalokra fókuszálva, 
Morvay Szabolcs: Európa Kulturális Fôvárosa projekt: A veszprémi, gyôri és debreceni...

1. táblázat: Kulturális és múvészeti tartalom kulcsszavakban, Györ

\begin{tabular}{|c|c|c|}
\hline \multicolumn{3}{|c|}{ UTAK } \\
\hline Tematikus utak & Kert program & Tematikus Utca Fesztivál \\
\hline $\begin{array}{l}\text { Debrecen-Nürnberg kereske- } \\
\text { delmi tengely }\end{array}$ & Új szabadtéri helyszínek & $\begin{array}{l}\text { Nemzetközi utcaszínházi pro- } \\
\text { dukciók }\end{array}$ \\
\hline $\begin{array}{l}\text { Pest-Buda-Drezda céhlegény- } \\
\text { tengely }\end{array}$ & $\begin{array}{c}\begin{array}{c}\text { Európai kertek kultúrtör- } \\
\text { ténete }\end{array} \\
\end{array}$ & $\begin{array}{c}\text { Utazás, menekülés témájának } \\
\text { feldolgozása }\end{array}$ \\
\hline $\begin{array}{c}\text { Duna-Majna-Rajna hajózási } \\
\text { tengely }\end{array}$ & $\begin{array}{c}\text { Kertészeti ismeretek- } \\
\text { egyetemi képzés }\end{array}$ & Európa „La Strada” fesztiváljai \\
\hline $\begin{array}{l}\text { Szent László-út - A keresztény- } \\
\text { ség útja }\end{array}$ & Nemzeti Kastélyprogram & \\
\hline Nagyvárad-Párizs vasúti tengely & & \\
\hline Menekülő települôk útjai & & \\
\hline \multicolumn{3}{|c|}{ VÁROS } \\
\hline Városlakók & Jelek & Városmúhely \\
\hline $\begin{array}{c}\text { Városrészek lakóinak kötődése } \\
\text { a városhoz }\end{array}$ & Jelképek születése & Virtuális fórum \\
\hline \multirow[t]{5}{*}{ Helytörténeti gyújtemény } & Az EKF-év megörökítése & Gyơri építészképzés \\
\hline & Zászló-projekt & Ipari formatervezés \\
\hline & Torony-projekt & Várostervezés \\
\hline & Sétány-projekt & Design \\
\hline & & $\begin{array}{l}\text { Városi terek formálása } \\
\text { vagy „felöltöztetése” }\end{array}$ \\
\hline Legyen a Te helyed & Városnap & \\
\hline Közönségfórum & A „győriség” ünnepe & \\
\hline \multicolumn{3}{|c|}{ PÁRBESZÉD } \\
\hline A barokkról & Táncról & Zenéról \\
\hline Barokk bál & Gyóri Balett & Győri Filharmonikus Zenekar \\
\hline Barokk esküvő & Magyar Táncfesztivál & Zenélő Duna Fesztivál \\
\hline \multicolumn{3}{|l|}{ Barokk belváros } \\
\hline Generációk között & Vallások között & Képzőmúvészetben \\
\hline Győrkőcfesztivál & Öt templom Fesztivál & Torula Múteremház \\
\hline \multirow[t]{6}{*}{$\begin{array}{c}\text { Fesztivál fogadó - } \\
\text { helyszín a találkozásra és pár- } \\
\text { beszédre }\end{array}$} & & $\begin{array}{l}\text { Rómer Flóris Múvészeti és } \\
\text { Történeti Múzeum }\end{array}$ \\
\hline & & Belvárosi kiállítóhelyek \\
\hline & & Újvárosi klasszikus mútermek \\
\hline & & $\begin{array}{c}\text { Új kiállítási és konferencia- } \\
\text { központ } \\
\end{array}$ \\
\hline & & Napóleon-ház \\
\hline & & Apátúr-ház \\
\hline
\end{tabular}

Forrás: Saját szerkesztés Györ MJV Önkormányzata, 2018 alapján 
akik Győr jövőjének formálói lehetnek. Célként jelenik meg a szándék, hogy a kulturális élményekkel, kreatív „színekkel” a gyoori polgárok, illetôleg az újonnan gyôrivé vált polgárok helyi identitását erôsítsék. A harmadik pillér, a „Párbeszéd” csomag a gyôri kreatív szektort, múvészeket, fiatalokat, idősebbeket igyekezett megszólítani, a kultúra dimenziójáról kívánt párbeszédet folytatni. Mindezen pilléreket átkarolta az elképzelés, hogy a közönség aktív részese legyen a múvészeti és kulturális tartalmaknak, átélve ezzel az áramlás élményét. A programok és események megoszlottak volna aszerint, hogy a felvezetó évekre vagy az EKF-évre tervezték, illetôleg sok program mindkét idôszakban zajlott volna. Túlnyomó többségben a teljes idôszakot átölelố programokat terveztek Gyốrben (1. táblázat).

Veszprém az Öt zászlóshajó projekt (2. táblázat) keretén belül a kulturális projekt struktúrájának négy pillérét határozta meg, ezek: Az árnyékunkon túl, A határainkon túl, A zsivajon túl, A bájon és elszigeteltségen túl. A kulturális és múvészeti tartalom kialakítása meghatározott elvek mentén történt, mint a szezonalitás leküzdése, a fenn-

\section{2. táblázat: Kulturális és múvészeti tartalom kulcsszavakban, Veszprém}

\begin{tabular}{c|c|c|c}
\hline \multicolumn{4}{|c}{ VESZPRÉM } \\
\hline Árnyékunkon túl & Határainkon túl & Zsivajon túl & Bájon és elszigeteltségen túl \\
\hline Kulturális profil & Régiós hálózatok & Hit & Elfeledett helyek \\
\hline Kreatív ipar & Balaton & Önismeret & Gasztronómia \\
\hline Zene & Kortárs irodalom & Városi terek & Borkultúra \\
\hline Előadó-múvészetek & & Kisebbségek & Vidéki élet \\
\cline { 3 - 4 } & & Nemi szerepek & Természet \\
\hline
\end{tabular}

Forrás: Saját szerkesztés Veszprém MJV Önkormányzata, 2018 alapján

\section{3. táblázat: Kulturális és múvészeti tartalom kulcsszavakban, Debrecen}

\begin{tabular}{|c|c|c|}
\hline \multicolumn{3}{|c|}{ DEBRECEN } \\
\hline Botanica reloaded & Debrecen hyppe & Cool craft \\
\hline Egyedi természeti adottságok & Debreceni Értéktár & Céhes kultúra \\
\hline Hortobágy & Déri Múzeum & Kézmúves mesteremberek \\
\hline Sonkádi templom & Alföldi nyomdászat & Debreceni „piacozás” \\
\hline Botanikus kert & Cifraszúrô & \\
\hline Debreceni Virágkarnevál & Debreceni páros kolbász & \\
\hline Send a letter & Global locals & Transit \\
\hline Alföld, irodalmi folyóirat & Sokszínúség & Debrecen Európa végpontja \\
\hline Debreceni Egyetem & Vallási felekezetek & Európai szintû́ programok \\
\hline Református Kollégium könyvtára & $\begin{array}{l}\text { Debreceni Egyetem nem- } \\
\text { zetköziesedése }\end{array}$ & Nemzetközi partnerség \\
\hline Egyetemi és Nemzeti Könyvtár & & \\
\hline
\end{tabular}

Forrás: Saját szerkesztés Debrecen MJV Önkormányzata, 2018 alapján 
Morvay Szabolcs: Európa Kulturális Fốvárosa projekt: A veszprémi, gyôri és debreceni...

tarthatóság, a nyelvi akadályok leküzdése, illetve hogy képesek legyenek megszólítani minden generációt.

Debrecen múvészeti és kulturális projektjének tartalma a már korábban felvezetett koncepcióra épült, vagyis a kéz motívuma által megtestesített gyakorlati tudásra, illetóleg a könyv megjelenítette elméleti tudásra. Ezt további hat témakörre bontották, melyek Debrecen sajátosságaiból, karakteréból, múltjából merítkeznek. A hat témakör eseménysorozatokban, nagyrendezvényekben, fesztiválokban aktivizálódott volna (3. táblázat).

\section{PARTNERSÉGEK}

Győr a korábbi és későbbi kulturális fôvárosok képviselőivel is kapcsolatot kívánt létrehozni. Egy már meglévô projekt keretében, a Duna-projekten keresztül Linz, illetve Novi Sad városok képviselőivel kapcsolat áll fenn, Galway városával szakrális örökség kapcsán alakult ki partnerség.

Veszprém közös projektet tervez Nottinghammel, Belfasttal és Dundeeval. Emellett a korábbi EKF-címbirtokosokkal tanácsadói minôségben kapcsolatot kíván teremteni, így Pécset is kiemelt szövetségesének tekinti.

Debrecen pályázatában legfôképpen a már meglévô kulturális-múvészeti kapcsolatait emeli ki, mutatja be, melyeket a saját kulturális intézményei alakítottak ki az elmúlt években. Az EKF kapcsán azonban új kapcsolatok kialakítását is tervezte:

- dizájnegyetemekkel, mint a Design Academy Eindhoven, Konstfack University of Arts, Craft and Design Stockholm;

- múzeumokkal (MAK, Bécs);

- múvész rezidens programokkal (WrocławAiR program, Plants AiR Novi Sad, The Bridge Guard Stúrovo, KulturKontakt Austria, Port Cultural Cetate stb.);

- építészeti központokkal (4AM Forum for Architecture and Media Brno, Vilniusi Egyetem Építészettörténeti és Kultúrtörténeti Tanszéke);

- kortárs múvészeti centrumokkal (OK Kulturzentrum Linz, Varsói Modern Múvészeti Múzeum);

- filmakadémiákkal és filmes platformokkal (Bécsi Filmakadémia, Potsdami Filmfőiskola, EU XXL - Forum for European Film).

\section{SZERVEZETI FELÉPÍTÉS}

A három város az EKF-projekt megvalósítása mögött álló szervezeti keretet különbözô formában képzelte el. A szervezeti felépítések összetett, több szereplóbôl álló struktúrák, meghatározott funkciókkal és felelősségi körökkel felruházott tagokkal. Gyôr az egyetlen város, amely nem kívánt egy külön projektcéget létrehozni a program irányítására, míg Debrecen már 2016-ban létrehozta, Veszprém pedig tervezi egy nonprofit kft. megalakítását. Közös a kigondolt szervezeti felépítések között, hogy nagy hangsúlyt fektettek volna az ellenőrzés megvalósulására a projekt során. A kontrollszerepet Debrecen esetében a Debrecen Kultúrájáért Alapítvány töltötte volna be, míg Veszprém esetén egy külön létrehozott EKF-bizottság feladata lesz. Elkülönül a 
múvészeti területért, a gazdasági területért, valamint a kommunikációért, marketingért felelôs igazgatói poszt a városok esetében. Győr tekintetében nagyobb szerepet kaptak volna a múvészeti, kulturális, oktatási intézmények a projekt kapcsán, a másik két városnál ilyen típusú intézmények nem jelentek meg szereplőként a szervezeti keretben.

\section{KON KLÚZIÓ}

A három város pályázatának összehasonlításából kitûnik, hogy izgalmas versenyt tudnak maguk mögött az EKF-címet elnyerni vágyott települések. Ma már tudjuk, hogy Veszprém városa nyert, azonban mindhárom város rendelkezik potenciállal a kultúra terén, illetve számos egyedi vonással. A városok kulturális stratégiáikban merítkeznek történelmi gyökereikből, megelevenítik az évszázadokat, amelyek formálták, kialakították mai kulturális palettájukat, gazdagították kulturális kincsestárukat. Építenek a régiós környezetükre, kapcsolataikra, nemzetközi dimenziókban gondolkodnak, illetve fontosnak vélik a kreatív és kulturális gazdaság egyre nagyobb szerepét a városi gazdaságszerkezetben, amiból fakadóan igyekeznek gazdaságfejlesztési kérdésként kezelni ezen szférák múködésének sikeresebbé tételét. Mindegyik elemzett város jelentôs kulturális költségvetéssel rendelkezik, mindemellett elkötelezett e tétel évrôl évre való növelésében. Óriási szerepet kap a városokban a kulturális infrastruktúra fejlesztése, korszerúsítése, megújítása, illetve teljesen új kulturális helyszínek, kulturális közegek megteremtése, és ami biztató, nemcsak az EKF-projektból következóen előirányozva, hanem új kulturális stratégiákban és koncepciókban kötelezték el magukat a városok ezen szándék megvalósulásában. A városokban él egyfajta vágy arra, hogy megmutassák értékeiket a külsố szemlélóknek, európai polgároknak, európai dimenzióban. Fel akarnak túnni Európa kulturális térképén, de közvetíteni is igyekeznek Európa számára saját értékeikból. Kulturális tartalmakban, elképzelésekben, ötletekben nem volt hiány egyik város esetében sem, programok tárházát vázolták fel rövid idôn belül, és alakították ki ennek strukturált, megszervezhetô, kivitelezhetô vázlatát. A programok, tartalmak erôsen gyökereztek a városok sajátos karakterében, jellegében és adottságaiban, illetve kifejezetten építettek külsô partnerekre, kapcsolatokra. A városok ismerik a mindenkori múvészeti világ trendjeit, nagyjait, ikonjait, és mindhárom város kiemelt egy-egy múvészeti ágat, irányzatot, melyben leginkább megtalálja önmagát. Gyoor gazdaságilag jobban a projekt mögé tudott volna állni, illetve földrajzi elhelyezkedése is kedvezôbb, Debrecen is megérdemelte volna a címet, végül Veszprém nyert. A bírálóbizottság döntési szempontrendszere sokrétú, kvalitatív, illetve puha elemeket is számba vesz, vélhetóleg benyomásokra is támaszkodott, és ugyancsak reagált hangulati elemekre (Balaton). Ugyanakkor Veszprém városának kitörési pontot is jelenthet az EKF-cím, illetve a Balaton is célzott fejlesztési pólus. Mindenesetre 2023-ban nemcsak Veszprém túnik majd ki a kulturális kincsei révén, hanem az egész ország figyelmet kap európai viszonylatban, mely vitathatatlanul mindannyiunk érdeke. 


\section{JEGYZETEK}

1 Az Európai Parlament és a Tanács 445/2014/EU határozata az Európa Kulturális Fôvárosa kezdeményezés 2020-2033. évekre szóló uniós fellépésének létrehozásáról és az 1622/2006/EK Határozat hatályon kívül helyezésérôl.

2 http://clld.arrabona.eu/clld.html.

3 http://investinveszprem.com/.

4 Veszprém MJV kulturális koncepciója. Kulturális Helyzetértékelés, 2014.

5 Debrecen MJV Településfejlesztési Koncepciója és Integrált Településfejlesztési Stratégiája 2014-2020. Megalapozó vizsgálat. www.debrecen.hu/assets/media/file/hu/4820/debrecenmjv-its-megalapozo-2017.pdf.

\section{FELHASZNÁLT IRODALOM}

Czakó Katalin - Dőry Tibor (2016): A területi tôke koncepciója és a városi vállalkozáskutatás. Tér és Társadalom, 30. évf., 1. sz., 18-36, https://doi.org/10.17649/tet.30.1.2699.

Debrecen MJV Önkormányzata (2018): Debrecen - Európa Kulturális Fôvárosa 2023 Pályázat. www.debrecen.hu/assets/media/file/hu/18332/debrecen-europa-kulturalis-fovarosa-2023-palyazat.pdf.

EC (2009): European Capitals of Culture: the Road to Success from 1985 to 2010. European Communities, Belgium.

EC (2018): European Capitals of Culture 2020 to 2033. A Guide for Cities Preparing to Bid. European Commission.

Egry Dóra (2010): Az Európa Kulturális Fôvárosa Pécs, 2010 program keretében megvalósuló kulturális intézmények. Szín, 15. évf., 6. sz., 94-104.

Faragó László (2010): Pécs fejlôdési pályája - Egy pécsi polgár szemével. Területfejlesztés és Innováció, 4. évf., 1. sz., 2-14.

Faragó László (2011): Az Európa Kulturális Fôvárosa program városfejlesztési, városirányítási tanulságai. In: Ágoston Zoltán (szerk.): Elemzô értékelés a Pécs 2010 Európa Kulturális Fốvárosa program tapasztalatairól. Pécs Megyei Jogú Város Önkormányzata, Pécs, 61-74.

Faragó, László (2012): Urban Regeneration in a "City of Culture" the Case of Pécs, Hungary. European Spatial Research and Policy, Vol. 19, No. 2, 103-120, https://doi.org/10.2478/v10105-012-0017-4.

Fekete, Dávid (2018a): Economic Development and Economic Governance Through the Example of the City of Győr. Deturope - The Central European Journal of Regional Development and Tourism, Vol. 10, No. 1, 97-115.

Fekete Dávid (2018b): Gyôri fejlesztések a Modern Városok Program keretében. Területi Statisztika, 58. évf., 6. sz., 638-658, https://doi.org/10.15196/ts580605.

Fekete Dávid - Rechnitzer János (2019): Együtt nagyok. Város és vállalat 25 éve. Dialóg Campus Kiadó, Budapest.

Glied Viktor (2014): A határtalan város határai - „Civilek” és az Európa Kulturális Fôvárosa Pécs2010 program. In: Tuka Ágnes - Glied Viktor (szerk.): Pécs a többszintú kormányzás csapdájában. IDResearch Kft. - Publikon, Pécs, 173-202.

Grünhut Zoltán (2013): A pécsi Európa Kulturális Fóvárosa projekt infrastrukturális beruházásai a többszintú döntéshozatal rendszerében. In: Karlovitz János T. (szerk.): Társadalomtudományi gondolatok a harmadik évezred elején. International Research Institute, Komárno, 100-107.

Győr MVJ Önkormányzata (2018): Győr 2023 Európa Kulturális Fôvárosa pályázat. http://2023gyor.hu/ wp-content/uploads/2017/11/onkormanyzat-EKF-HU-alairt.pdf.

KSH (2013a): 2011. évi népszámlálás. 3. Területi adatok. 3.9. Hajdú-Bihar megye. Központi Statisztikai Hivatal, www.ksh.hu/docs/hun/xftp/idoszaki/nepsz2011/nepsz_03_09_2011.pdf.

KSH (2013b): 2011. évi népszámlálás. 3. Területi adatok. 3.19. Veszprém megye. Központi Statisztikai Hivatal, www.ksh.hu/docs/hun/xftp/idoszaki/nepsz2011/nepsz_03_19_2011.pdf.

KSH (2014): Magyarország településhálózata I. Agglomerációk, településegyüttesek. Központi Statisztikai Hivatal, Budapest. 
Ooi, Can-Seng - Hakanson, Lars - Lacava, Laura (2014): Poetics and Politics of the European Capital of Culture Project. Procedia - Social and Behavioral Sciences, Vol. 148, 420-427, https://doi.org/10.1016/j. sbspro.2014.07.061.

Palmer, Robert - Richards, Greg (2007): European Cultural Capital Report. Atlas, Arnhem.

Pálné Kovács Ilona (2010): Tudás, közösség, kormányzás: EKF párhuzamok. Echo, 13. évf., 5-6. sz., 12-14.

Pálné Kovács, Ilona (2013): Pécs, As the Victim of Multi-Level Governance: the Case of the Project "European Capital of Culture" in 2010. Urban Research and Practice, Vol. 6, No. 3, 365-375, https://doi.org/10. 1080/17535069.2013.827907.

Pálné Kovács Ilona (2014): Kulturális fôvárosok Európában, kormányzási kihívások. In: Tuka Ágnes - Glied Viktor (szerk.): Pécs a többszintú kormányzás csapdájában. IDResearch Kft. - Publikon, Pécs, 39-61.

Rechnitzer János (2016): A területi tôke a városfejlôdésben. A Gyôr-kód. Dialóg Campus, Budapest-Pécs.

Schmidt Andrea (2014): Az Európa Kulturális Fôvárosa gazdasági hatásai. In: Tuka Ágnes - Glied Viktor (szerk.): Pécs a többszintú kormányzás csapdájában. IDResearch Kft. - Publikon, Pécs, 204-223.

Takáts József (2007): A pécsi kísérlet. Korunk, 18. évf., 1. sz., 83-89.

Tóthné Kardos Krisztina (2016): A gyôri turizmus elemzése a lakosság véleményének figyelembevételével. Polgári Szemle, 12. évf., 4-6. sz.

Tuka Ágnes - Glied Viktor (szerk.) (2014): Pécs a többszintú kormányzás csapdájában. IDResearch Kft. - Publikon, Pécs.

Veszprém MJV Önkormányzata (2018): Veszprém 2023 Európa Kulturális Fơvárosa pályázat. http:// 2023veszprem.hu/app/uploads/2017/09/Bid_book_2018_HU-1.pdf. 